\title{
Groups 4 and 15 and Organotin Condensation Polymers for The Treatment of Cancers and Viruses
}

\author{
Charles E Carraher Jr ${ }^{1 *}$, Michael R Roner ${ }^{2}$, Paul Slawek ${ }^{1}$, Francesca Mosca ${ }^{1}$, Jessica Frank ${ }^{1}$ and Lindsey Miller ${ }^{2}$ \\ ${ }^{1}$ Florida Atlantic University, Department of Chemistry and Biochemistry, Boca Raton, FL 33431, USA
}

${ }^{2}$ University of Texas at Arlington, Department of Biology, Arlington, TX 76010, USA

*Corresponding author: Charles E Carraher, Department of Chemistry and Biochemistry, Boca Raton, USA

\begin{abstract}
This short review describes the use of group 4 metallocenes, group 15 organometallics and organotin polymers in the treatment of human cancer tumors and viruses. These metal-containing polymers show good inhibition of all the main group solid tumors including pancreatic, lung, brain, breast, prostate and colon human cell lines. They also show inhibition of a variety of viruses including zika, herpes and vaccinia viruses. Synthesis of the polymers is rapid employing interfacial polymerization and commercially available reactants. They offer physicians a new class of drugs for the treatment of a variety of cancers and viruses.
\end{abstract}

Keywords: Cancer; Viruses; Interfacial polymerization; Brain cancer; Pancreatic cancer; Zika virus; Vaccinia virus, Breast cancer, Herpes virus

\section{Introduction}

Use of metal-containing agents to treatvarious medical problems is well known [1-22]. Here the focus is on activities to supply metalcontaining polymers for the treatment of various cancers and viruses. While we have had extensive experience with platinum and palladium polymers for the treatment of a variety of cancers, the current emphasis is on polymers formed by incorporation of groups 4 and 15 metals and organotin condensation polymers for the treatment of cancers and viruses [23-41]. These two polymer types are different with their own separate biological characterizations [26]. For instance, the platinum and palladium polymers are addition products and not stable for long times in solution. By comparison, the groups 4 metallocene and organotin and group 15 polymers are condensation polymers and exhibit good stability to over 30 weeks in solution so can be treated differently with respect to biological and physical characterizations [26-41].

\section{Synthesis}

Synthesis occurs employing interfacial polymerization [4246]. It is a rapid polymerization system because high-energy reactants are employed. These high-energy reactants are acid halides. A typical condensation reaction has an activation energy of about $30-40 \mathrm{Kcal} / \mathrm{mol}$ whereas the activation energy for the acid halide reactions is on the order of $20 \mathrm{Kcal} / \mathrm{mol}$. The interfacial polymerization is employed industrially to synthesize aromatic polyamides (nylons) and polycarbonates so industry is familiar with the system $[47,48]$. These interfacial polycondensation reactions form polymer within less than one minute in decent yield. For the syntheses described here, commercially available reactants are employed allowing ready reproduction and scale-up to ton levels in a somewhat straightforward manner. Rapid stirring is employed, generally about $18,000 \mathrm{rpm}$. This allows both the rapid 
polymerizations to occur with an increase in interfacial contact area of over ten thousand compared to non-stirred systems, and good reproducibility. For the systems described here, the reaction vessel is a simple glass reaction vessel, one-quart Kimax emulsifying jar, fitted onto a Waring Blender. To illustrate the overall reactions, products formed for the organotin polymers have a repeat unit described as follows.

$$
\mathrm{R}_{2} \mathrm{SnX}_{2}+\mathrm{X}-\mathrm{R}-\mathrm{Y} \rightarrow-\left(-\mathrm{SnR}_{2}-\mathrm{R}-\right)-
$$

where $\mathrm{X}$ and $\mathrm{Y}$ are normally Lewis bases such as alcohols, amines, acid salts, thiols, etc. These reaction sites are often varied for a single Lewis base such as an amino acid, shown below, that has both acid and amine reactant sites. Examples of overall reaction products for each of the three condensation polymer groups are given following. Reaction between the amino acid diglycine and dimethyltin dichloride is described (Figure 1). The polymer is described as a poly (amine ester) with the organotin unit considered an organic moiety such as a methylene unit in such naming. For the Group 4 metallocenes, the reaction employing titanocene dichloride as the Lewis acid, the repeat unit for a product formed from titanocene dichloride and chelidonic acid is given (Figure 2). Finally, for reactions involving group 15 metals, the repeat unit formed from reaction between triphenylantimony dichloride and 3,5-pyridinedicarboxylic acid forming a polyester is given (Figure 3). The metal is generally located in the Lewis acid portion while the non-metal reactant is the Lewis base. In certain cases, the Lewis base portion may also contain a metal, usually iron and cobalt. The iron is present as a ferrocene while the cobalt is present as a cobaltocene [32].

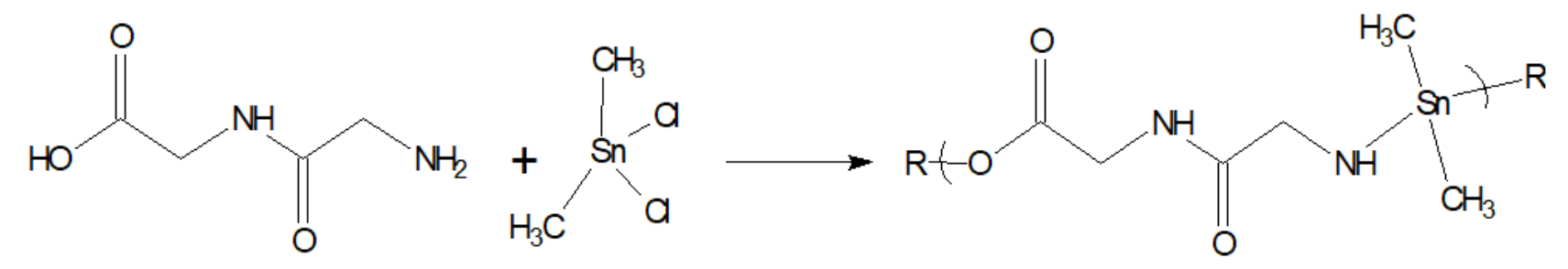

Figure 1: Synthesis of organotin poly (amine esters) from reaction of diglycine and dimethyltin dichloride where R represents simple chain extension.<smiles>O=C(O)c1cc(=O)cc(C(=O)O)o1</smiles><smiles></smiles>

Figure 2: Synthesis of polyesters from reaction with titanocene dichloride and chelidonic acid where R represents simple chain extension.

\section{Cancer}

It was initially mistakenly assumed that these metal-containing compounds inhibited cancer by the same mechanism as the platinum-containing drugs as cisplatin and other similar platinum containing drugs [26,50]. (The platinum-containing drugs currently are employed in over $60 \%$ of the chemo drug treatments generally as one of the components.) It is now known that this is not true so that they can be coupled with the drugs described here as co-drugs that will affect inhibition of cancer through two distinct avenues. The platinum-containing drugs are quite toxic resulting in the presence of many negative side effects [26]. Our effort is to create drugs that have similar or superior ability to inhibit cancer but without the unwanted side effects. All of the metal-containing drugs operate primarily on the DNA site for inhibition of the cancer cell lines $[26,50]$.

The polymers synthesized by us have shown good ability to inhibit a variety of cancer cell lines Table 1 . These cell lines represent all of the major human solid tumor cell lines. These cell lines include resistant cells meaning cell lines that have shown ability to resist treatment with the traditional anticancer drugs [39] (Table 1). Inhibition depends on the metal atom present as well as the nature of the Lewis base. With respect to the metal, in general, inhibition 
is of the order $\mathrm{Hf}=\mathrm{Zr}>\mathrm{Ti}>\mathrm{Sn}>\mathrm{Sb}, \mathrm{Bi}$, As. Inhibition is also dependent on the specific Lewis base. A primary measure of the ability for a drug to inhibit cancer growth is the effective concentration, EC. The $50 \%$ effective concentration, $\mathrm{EC}_{50}$, is the concentration of a toxicant, drug, or antibody that induces an inhibitory response halfway between the baseline and maximum after a specified exposure time. The desired outcome is to have low $\mathrm{EC}_{50}$ values as this indicates that only a small concentration of the anti-cancer agent is needed to elicit inhibition. For the compounds described here, once inhibition begins, the slope of the dose/concentration curve is high with inhibition being total. Depending on the specific Lewis acid/base the $\mathrm{EC}_{50}$ value is typically between milligrams $/ \mathrm{mL}$ to nanograms $/ \mathrm{mL}$. The metal-containing compounds are often coupled with a Lewis base that exhibits some biological activity hoping for a syngeneic effect. Drugs that have been employed as the Lewis bases include ciprofloxacin, diethylstilbestrol, cephalexin, acyclovir, thiamine, dicumarol, camphoric acid, histamine, 2-ketoglutaric acid, salicylic acid, dipicolinic acid, isomanide, glycyrrhetinic acid, phentolamine, thiodiglycolic acid. Lewis bases that themselves exhibit no ability to inhibit cancer can also exhibit good inhibition when coupled with a metal-containing moiety. These include a wide variety of diols such as ethylene glycol, Figure 4 [29,50]. Recently, water-soluble drugs possessing the metal-containing unit were synthesized [29] employing as the Lewis base poly (ethylene glycol), PEG. The resulting water-soluble polymers exhibit good inhibition of the cell lines. Figure 5 contains the reaction between titanocene dichloride and PEG forming water soluble polyethers (Figures $4 \& 5$ ).

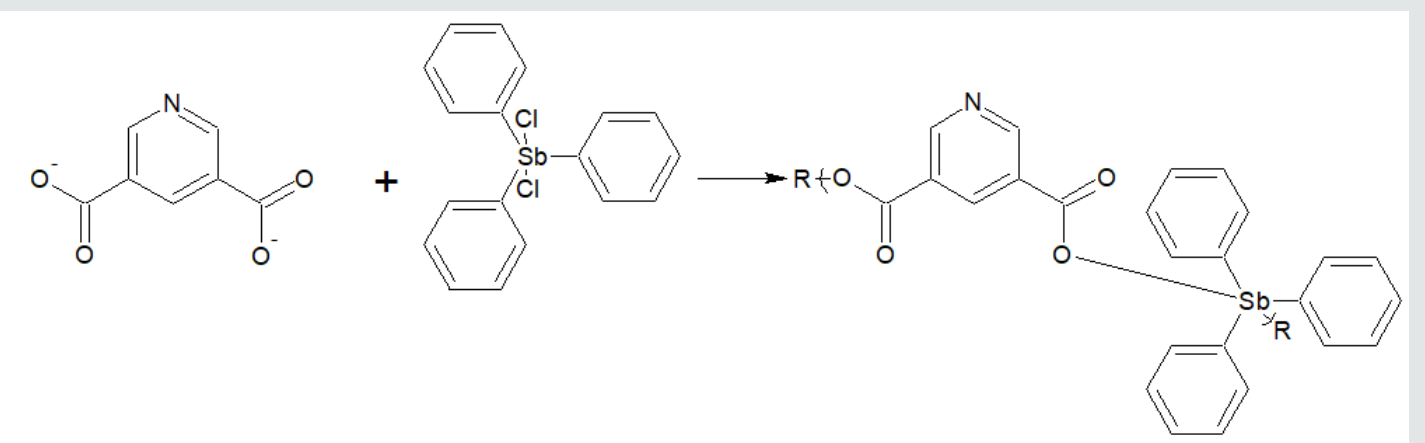

Figure 3: Synthesis of triphenylantimony polyesters from reaction with 3,5-pyridinedicarboxylic acid where $\mathrm{R}$ is simple chain extension.

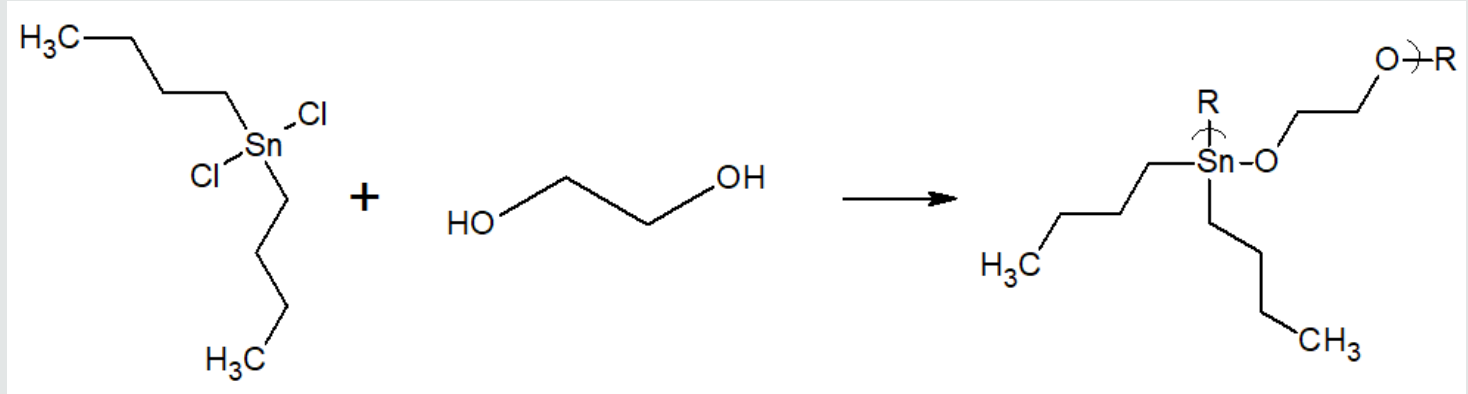

Figure 4: Reaction between ethylene glycol and dibutyltin dichloride forming polyethers.

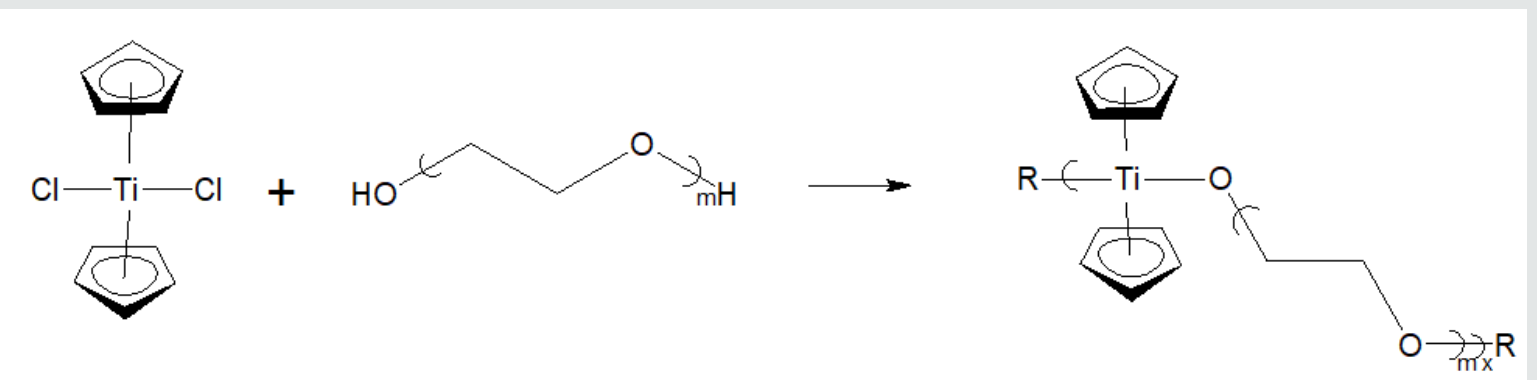

Figure 5: Formation of water-soluble polyethers from reaction of titanocene dichloride and various poly (ethylene oxides) where R represents simple chain extension.

\section{Viruses}

These metal-containing polymers also inhibit a variety of viruses including ones where no current drugs are available for treatment $[40,41,49]$. Table 2 contains viruses that have been inhibited by our metal-containing drugs including most recently the zika virus. These viruses include both DNA and RNA viruses. 
They include several that have been identified as possible weapons of mass destruction, namely the vaccinia virus. Three DNA viruses are effectively inhibited by the metal-containing polymers (Table 2 ). They are the vaccinia virus used to vaccinate humans against smallpox; herpes simplex virus 1, the virus responsible for over Table 1: Caner cell lines inhibited by metal-containing polymers
45 million infections yearly in the US, comprising one of five adolescents and adults; and the varicella zoster virus, also a herpes virus and responsible for chickenpox and shingles. Thus, the metalcontaining polymers represent a possible potent approach towards inhibiting unwanted viruses (Table 2).

\begin{tabular}{|c|c|c|c|c|}
\hline Strain Number & NCI Designation & Species & Tumor Origin & Histological Type \\
\hline 3465 & PC-3 & Human & Prostate & Carcinoma \\
\hline 7233 & MDA MB-231 & Human & Pleural effusion breast & Adenocarcinoma \\
\hline 1507 & HT-29 & Human & Recto-sigmoid colon & Adenocarcinoma \\
\hline 7259 & MCF-7 & Human & Pleural effusion-breast & Adenocarcinoma \\
\hline ATCC CCL-75 & WI-38 & Human & Normal embryonic lung & Fibroblast \\
\hline CRL-1658 & $\mathrm{NIH} / 3 \mathrm{~T} 3$ & Mouse & $\begin{array}{l}\text { Embryo-continuous cell line of highly contact- } \\
\text { inhibited cells }\end{array}$ & Fibroblast \\
\hline ATCC DDL-1658 & WI-38 VA13 2RA & Human & $\begin{array}{l}\text { Normal embryonic lung transformed with SV-40 } \\
\text { virus }\end{array}$ & Fibroblast \\
\hline L929 & & Mouse & Connective tissue transformed & Fibroblast \\
\hline 143 & & Human & Osteosarcoma bond cells & Fibroblast \\
\hline \multirow[t]{5}{*}{ Vero } & & Monkey & Epithelial cells & Fibroblast \\
\hline & AsPC-1 & Human & Pancreatic cells & Adenocarcinoma \\
\hline & PANC-1 & Human & Epithelioid pancreatic cells & Carcinoma \\
\hline & U251 & Human & Glioblastoma multiforme & Astrocytomas \\
\hline & G55 & Human & Glioblastoma & Astrocytomas \\
\hline ATCC CCL 163 & & Mouse & $\begin{array}{l}\text { Embryo-continuous cell line of partially } \\
\text { transformed cells }\end{array}$ & Fibroblast \\
\hline ATCC HTB 75 & & Human* & Ovary & Adenocarcinoma resistant cells \\
\hline АТСС НТВ 161 & & Human** & Ovary & Adenocarcinoma resistant cells \\
\hline
\end{tabular}

From a cancer patient with ovarian cancer that had previously been treated with cytoxan, adriamycin, 5-fluorouracil, and Fur IV. From a cancer patient with ovarian cancer that had been treated with adriamycin, cyclophosphamide, and cisplatin.

Table 2: Viruses inhibited by metal-containing polymers discussed in this report.

\begin{tabular}{|c|c|c|c|c|}
\hline Virus & Disease in humans & Viral genome & $\begin{array}{c}\text { Virus replication in } \\
\text { cytoplasm or nucleus }\end{array}$ & $\begin{array}{c}\text { Current antiviral drugs } \\
\text { (CDC recommendations) }\end{array}$ \\
\hline Zika virus (502) & $\begin{array}{c}\text { Microcephaly, Guillain- } \\
\text { Barré syndrome (GBS) }\end{array}$ & Single-stranded RNA & Cytoplasm & None \\
\hline $\begin{array}{c}\text { Vaccinia virus (WR) } \\
\text { (Vaccine strain for } \\
\text { smallpox) }\end{array}$ & Vaccine strain for smallpox & Double-stranded DNA & Cytoplasm & $\begin{array}{c}\text { Vaccine, Tecovirimat, } \\
\text { Cidofovir, Brincidofovir }\end{array}$ \\
\hline HSV-1 (Herpes simplex-1) & Herpes & Double-stranded DNA & Nucleus & $\begin{array}{c}\text { Acyclovir, Valacyclovir, } \\
\text { Famciclovir }\end{array}$ \\
\hline HSV-2 (Herpes simplex-2) & Herpes & Double-stranded DNA & Nucleus & $\begin{array}{c}\text { Acyclovir, Valacyclovir, } \\
\text { Famciclovir }\end{array}$ \\
\hline VZV (Varicella Zoster) & Chickenpox/shingles & Double-stranded DNA & Nucleus & Vaccine, Acyclovir \\
\hline Reovirus & $\begin{array}{c}\text { Respiratory enteric orphan } \\
\text { virus }\end{array}$ & Double-stranded RNA & Cytoplasm & None \\
\hline
\end{tabular}

\section{Why Polymeric Drugs?}

A critical question is "Why Polymeric Drugs?" What advantageousness do polymeric drugs offer [50-60]. Following briefly describes some advantages. Each of these advantages is related to the size of polymers and what such size offers. First, because of their size, polymers travel through the body, in particular the kidney and bladder, more slowly lessening organ damage allowing the organs to limit the negative effect $[50,61]$. Second, cancer cells are less cohesive, offering greater porosity, and are not as coherent as normal cells with relatively "rough" exteriors. This allows polymers to have a greater opportunity to be "snagged" by the cancer cells allowing them extended ability to be associated with the cancer cells resulting in a greater ability to inhibit cell 
growth. This scenario is described as the enhanced permeability and retention effect [50,62-64]. Third, increased size allows for a greater designing of the drug increasing its effectiveness [65-69]. This fine tuning includes attachment of "biological homing agents". Thus, polymeric drugs offer advantageous over small molecule drugs that can be used to more effectively combat unwanted diseases compared to small molecule drugs.

\section{Summary}

Metal-containing polymers show ability to inhibit all the major solid tumor cancers as well as important viruses. They are easily synthesized and offer physicians new drugs to attack these harmful illnesses.

\section{References}

1. Ellahioui Y, Prashar S, Gómez Ruiz S (2017) Anticancer Applications and Recent Investigations of Metallodrugs Based on Gallium, Tin and Titanium. Inorganics 5(1): 4

2. Baiocco P, Colotti G, Franceschini S, Ilari A (2009) Molecular Basis of Antimony Treatment in Leishmaniasis. Journal of Medicinal Chemistry 52(8): 2603-2612.

3. Farrell N (1989) Platinum - Amine Complexes as Anticancer Agents. Transition Metal Complexes as Drugs and Chemotherapeutic Agents Catalysis by Metal Complexes 46-66.

4. Dasari S, Tchounwou PB (2014) Cisplatin in Cancer Therapy: Molecular Mechanisms of Action. European Journal of Pharmacology 740: 364-378.

5. Oun R, Moussa YE, Wheate NJ (2018) Correction: The Side Effects of Platinum-Based Chemotherapy Drugs: A Review for Chemists. Dalton Transactions 47: 7848-7848.

6. Apps MG, Choi EHY, Wheate NJ (2015) The State-of-Play and Future of Platinum Drugs. EndocrineRelated Cancer 22(4): 19-33.

7. Akter F (2017) Oropharyngeal Cancer. Encyclopedia of Cancer and Society.

8. Heidenreich A (2017) Testis Cancer. Oxford Medicine Online.

9. Mcwhinney SR, Goldberg RM, Mcleod HL (2009) Platinum Neurotoxicity Pharmacogenetics. Molecular Cancer Therapeutics 8(1): 10-16.

10. Ott I, Gust R (2007) Non Platinum Metal Complexes as Anticancer Drugs. Arch Pharm 340(3): 117-126.

11. Abdellah MA, Hadjikakou SK, Hadjiliadis N, Kubicki M, Bakas T, et al. (2009) Synthesis, Characterization, and Biological Studies of Organotin (IV) Derivatives with o- or p-Hydroxybenzoic Acids. Bioinorganic Chemistry and Applications 1(6): 12.

12. Carraher CE (2005) Uranium-Containing Polymers. Macromolecules Containing Metal and Metal-Like Elements 343-385.

13. Piver WT (1973) Organotin Compounds: Industrial Applications and Biological Investigation. Environmental Health Perspectives 4: 61-79.

14. Pieters RH, Bol M, Seinen W, Penninks AH (1994) Cellular and Molecular Aspects of Organotin-Induced Thymus Atrophy. Human \& Experimental Toxicology 13(12): 876-879.

15. Nath M, Vats M, Roy P (2015) Mode of Action of Tin-Based AntiProliferative Agents: Biological Studies of Organotin (IV) Derivatives of Fatty Acids. Journal of Photochemistry and Photobiology B: Biology 148: 88-100.

16. Rocamora Reverte L, Carrasco García E, Ceballos Torres J, Prashar S, Kaluđerović GN, et al. (2011) Study of the Anticancer Properties of Tin (IV) Carboxylate Complexes on a Panel of Human Tumor Cell Lines. ChemMedChem 7(2): 301-310.
17. Devi J, Pachwania S (2018) Recent Advancements in DNA Interaction Studies of Organotin (IV) Complexes. Inorganic Chemistry Communications 91: 44-62.

18. Rehman SU, Sarwar T, Husain MA, Ishqi HM, Tabish M (2015) Studying Non-Covalent Drug-DNA Interactions. Archives of Biochemistry and Biophysics 576: 49-60.

19. Hussain S, Ali S, Shahzadi S, Tahir MN, Shahid M (2015) Synthesis, Characterization, Biological Activities, Crystal Structure and DNA Binding of Organotin (IV) 5-Chlorosalicylates. Journal of Coordination Chemistry 68(14): 2369-2387.

20. Asanagi M, Yamada S, Hirata N, Itagaki H, Kotake Y (2016) Tributyltin Induces G2/M Cell Cycle Arrest via NAD+-Dependent Isocitrate Dehydrogenase in Human Embryonic Carcinoma Cells. The Journal of Toxicological Sciences 41(2): 207-215.

21. Varela Ramirez A, Costanzo M, Carrasco YP, Pannell KH, Aguilera RJ (2010) Cytotoxic Effects of Two Organotin Compounds and Their Mode of Inflicting Cell Death on Four Mammalian Cancer Cells. Cell Biology and Toxicology 27(3): 159-168.

22. Xanthopoulou MN, Hadjikakou SK, Hadjiliadis N, Milaeva ER, Gracheva JA, et al. (2008) Biological Studies of New Organotin (IV) Complexes of Thioamide Ligands. European Journal of Medicinal Chemistry 43(2): 327-335.

23. Carraher CE (2005) Organotin polymers. In Macromolecules Containing Metal and Metal-Like Elements 4.

24. Pellerito L, Nagy L (2002) Organotin (IV)n+ complexes formed with biologically active ligands: equilibrium and structural studies, and some biological aspects. Coordination Chemistry Reviews 224(1-2): 111-150.

25. Roner MR, Shahi KR, Barot G, Battin A, Carraher CE (2009) Preliminary Results for the Inhibition of Pancreatic Cancer Cells by Organotin Polymers. J Inorg Organomet P 19(3): 410-414.

26. Roner MR, Carraher CE, Shahi K, Barot G (2011) Antiviral Activity of Metal-Containing Polymers-Organotin and Cisplatin-Like Polymers. Materials 4(6): 991-1012.

27. Barot G, Shahi K, Roner MR, Carraher CE (2007) Synthesis, structural characterization, and ability to inhibit cancer growth of a series of organotin poly (ethylene glycols). Journal of Inorganic and Organometallic Polymer Materials 17: 595-603.

28. Carraher CE, Naoshima Y, Nagao K, Roner MR, Zhao A, et al. (2011) Antibacterial, Yeast and Fungal Polymeric Materials Derived from Organotin-Containing Materials J Polym Mater 28(3): 303-36.

29. Carraher CE, Roner MR (2009) Organotin Polyethers as potential biomaterials. Materials 2(4): 1558-1598.

30. Carraher CE, Roner MR (2009) Organotin Polyethers as Biomaterials. Materials 2(4): 1558-1598.

31. Carraher CE, Battin AJ, Roner MR (2013) Effect of Bulk Doping on the Electrical Conductivity of Selected Metallocene Polyamines. J Inorg Organomet P 23(1): 61-73.

32. Carraher CE (2005) Condensation Metallocene Polymers. JIOMP 15: 121-145.

33. Abd-El-Aziz A, Carraher CE, Pittman C, Sheats J, Zeldin M (2003) Macromolecules Containing Metal and Metal-Like elements, I. A Half Century of Metal-and Metalloid-Containing Polymers. Wiley.

34.Abd-El-Aziz A, Carraher CE, Pittman C, Sheats J, Zeldin M (2003) Macromolecules Containing Metal and Metal-Like Elements, II, Organoiron Polymers. Wiley.

35. Abd-El-Aziz A, Carraher CE, Pittman C, Sheats J, Zeldin M (2004) Macromolecules Containing Metal and Metal-Like Elements, III. Biomedical Applications. Wiley.

36. Abd El Aziz A, Carraher CE, Pittman C, Zeldin M (2004) Macromolecules Containing Metal and Metal-Like Elements, III. Wiley. 
37. Abd El Aziz A, Carraher CE, Pittman C, Zeldin M (2008) Inorganic and Orgnaometallic Macromolecles-Design and Application. Springer.

38. Siegmann Louda D, Carraher CE (2004) Polymeric platinum-containing drugs in the treatment of cancer,in Macromolecules Containing Metal and Metal-Like Elements. Vol. 3. Biomedical Applications. Wiley.

39. Siegmann Louda DW, Carraher CE, Pflueger F, Coleman J (2009) Biological activity of organotin polymers containing cephalexin against human ovary adenocarcinoma-resistant cell lines. Abstr Pap Am Chem S 219: U489.

40. Shahi K, Roner MR, Battin A, Carraher CE (2008) Ability of organotin pyrimidine polyamines to hinhibit HSV-1 (Herpes simplex virus) and Vaccinia (small pox virus) viruses. Polymeric Materials Science and Engineering 99: 365-377.

41. Roner MR, Carraher CE, Dhanji S, Barot G (2008) Antiviral and anticancer activity of cisplatin derives of tilorone. Journal of Inorganic and Organometallic Polymer Materials 18: 374-383.

42. Millich F, Carraher CE (1977) Interfacial Synthesis Dekker.

43. Millich F, Carraher CE (1977) Interfacial Synthesis. Vol. II. Dekker.

44. Millich F, Carraher CE, Preston J (1977) Interfacial synthesis. III. Dekker.

45. Song Y, Fan JB, Wang S (2017) Recent Progress in Interfacial Polymerization. Materials Chemistry Frontiers 1: 1028-1040.

46. Behera S, Suresh AK (2017) Kinetics of Interfacial Polycondensation Reactions - Development of a New Method and Its Validation. Polymer 127: 28-44.

47. Carraher CE (2017) Introduction to Polymer Chemistry, (4 ${ }^{\text {th }}$ edn), Taylor \& Francis.

48. Carraher CE (2018) Polymer Chemistry, 10th Ed. Taylor \& Francis.

49. Miller L, Roner MR, Carraher CE, Mosca F, Slawek P, et al. (2019) Organotin polymers as antiviral agents including inhibition of zika and vaccinia viruses. International Journal of Applied Pharmaceutical and Biological Research.

50. Carraher CE, Roner MR (2014) Organotin polymers as anticancer and antivirial agents. J. Organometallic Chemistry 751: 67-82.

51. Alama A, Tasso B, Novelli F, Sparatore F (2009) Organometallic compounds in oncology: implications of novel organotins as antitumor agents. Drug discovery today 14(9-10): 500-508.

52. Nebbia C, Dacasto M, Ceppa L, Gennaro Soffietti M, Spinelli P, et al. (1997) The comparative effects of subchronic administration of triphenyltin acetate (TPTA) on the hepatic and renal drug-metabolizing enzymes in rabbits and lambs. Vet Res Commun 21(2): 117-125.

53. Abd-El-Aziz A, Carraher CE, Pittman C, Sheats J, Zeldin M (2004) Macromolecules Containing Metal and Metal-Like Elements. Vol. 6. Transition Metal-Containing Polymers Wiley.

54. Luo Y, Prestwich GD (2002) Cancer-targeted polymeric drugs. Curr Cancer Drug Targets 2(3): 209-226.
55. Maeda H (2010) Tumor-selective delivery of macromolecular drugs via the EPR effect: background and future prospects. Bioconjug Chem 21(5): 797-802.

56. Fang J, Nakamura H, Maeda H (2011) The EPR effect: Unique features of tumor blood vessels for drug delivery, factors involved, and limitations and augmentation of the effect. Adv Drug Deliv Rev 63(3): 136-151.

57. Torchilin V (2011) Tumor delivery of macromolecular drugs based on the EPR effect. Adv Drug Deliv Rev 63(3): 131-135.

58. Fish RH (2010) A Bioorganometallic Chemistry Overview: From Cytochrome P450 Enzyme Metabolism of Organotin Compounds to Organorhodium-Hydroxytamoxifen Complexes with Potential Anti-Cancer Properties; A 37 Year Perspective at the Interface of Organometallic Chemistry and Biology. Australian Journal of Chemistry.

59. Tabassum S, Pettinari C (2006) Chemical and biotechnological developments in organotin cancer chemotherapy. J Organomet Chem 691(8): 1761-1766.

60. Tiekink ERT (2008) Tin dithiocarbamates: applications and structures. Applied Organometallic Chemistry 22(9): 533-550.

61. Goddard P, Williamson I, Brown J, Hutchinson LE, Nicholls J, et al. (1991) Soluble Polymeric Carriers for Drug Delivery .4. Tissue Autoradiography, and Whole-Body Tissue Distribution in Mice, of N-(2-Hydroxypropyl) Methacrylamide Copolymers Following Intravenous Administration. Journal of Bioactive and Compatible Polymers 6(1): 4-24.

62. Maeda H (2010) Tumor-selective delivery of macromolecular drugs via the EPR effect: background and future prospects. Bioconjug Chem 21(5): 797-802.

63. Fang J, Nakamura H, Maeda H (2011) The EPR effect: Unique features of tumor blood vessels for drug delivery, factors involved, and limitations and augmentation of the effect. Adv Drug Deliv Rev 63(3): 136-151.

64. Torchilin V (2011) Tumor delivery of macromolecular drugs based on the EPR effect. Adv Drug Deliv Rev 63(3): 131-135.

65. Abdellaoui K, Boustta M, Morjani H, Manfait M, Vert M (1998) Uptake and intracellular distribution of 4-aminofluorescin-labelled poly(Llysine citramide imide) in K562 cells. J Drug Target 5(3): 193-206.

66. Vasey PA, Kaye SB, Morrison R, Twelves C, Wilson P, et al. (1999) Phase I clinical and pharmacokinetic study of PK1 [N-(2-hydroxypropyl) methacrylamide copolymer doxorubicin]: first member of a new class of chemotherapeutic agents-drug-polymer conjugates. Cancer Research Campaign Phase I/II Committee. Clin Cancer Res 5(1): 83-94.

67. Chourasia MK, Jain SK (2004) Polysaccharides for colon targeted drug delivery. Drug Deliv 11(2): 129-148.

68. Fournier E, Passirani C, Colin N, Breton P (2004) Development of novel 5-FU-loaded poly(methylidene malonate 2.1.2)-based microspheres for the treatment of brain cancers. Eur J Pharm Biopharm 57(2): 189-197.

69. Ulbrich K, Subr V (2004) Polymeric anticancer drugs with pH-controlled activation. Adv Drug Deliv Rev 56(7): 1023-1050. 
(c) (P) This work is licensed under Creative

To Submit Your Article Click Here: $\quad$ Submit Article

DOI: 10.32474/MAMS.2018.01.000103

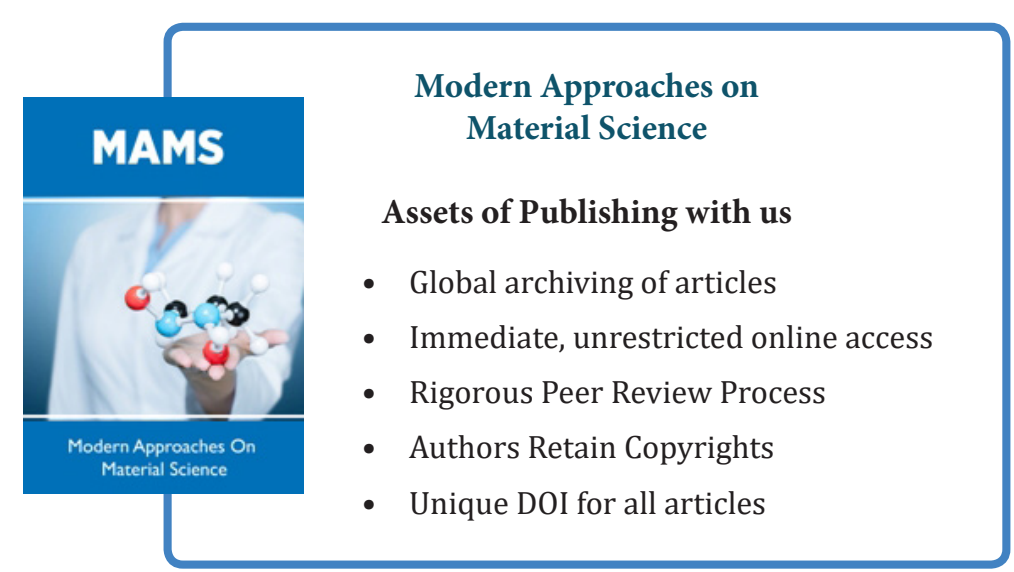

